\title{
EKSPLORASI NIAT PERILAKU WISATAWAN DENGAN PENGUJIAN MODEL TECHNOLOGY ACCEPTANCE MODEL DAN THEORY OF PLANNED BEHAVIOR (STUDI KASUS PADA ONLINE TRAVEL AGENT)
}

\author{
Putu Dyah Permatha Korry \\ Fakultas Ekonomi dan Bisnis, Universitas Pendidikan Nasional
}

\begin{abstract}
ABSTRAK
Selama ini kita melihat sudah banyak peneliti yang meneliti mengenai Technology Acceptance Model (TAM) dan Theory of Planned Behavior (TPB) terhadap niat perilaku yang berhubungan dengan e-commerce. Akan tetapi yang meneliti mengenai penggabungan kedua model tersebut dengan niat perilaku wisatawan dalam menggunakan sebuah teknologi itu belum ada. Pada penelitian penelitian saat ini berfokus pada niat perilaku wisatawan yang berkunjung ke Bali dengan menggunakan Online Travel Agent (OTA) dan dilihat juga dari perspektif gender. Responden dalam penelitian ini berjumlah 100 orang dengan menggunakan metode purposive sampling untuk teknik pengambilan sampelnya dengan kriteria wisatawan yang berasal dari luar Bali dan menggunakan jasa Online Travel Agent (OTA) untuk berkunjung ke Bali. Teknik analysis data yang digunakan dalam penelitian ini yaitu Structural Equation Modelling (SEM) yang menggunakan software Smart PLS (Partial Least Square). Hasil penelitian ini menunjukan bahwa sikap terhadap perilaku tidak berpengaruh terhadap niat perlaku, gender dalam sikap terhadap perilaku berpengaruh negatif terhadap niat perilaku, norma subjektif berpengaruh positif dan signifikan terhadap niat perilaku, gender dalam norma subjektif berpengaruh positif dan signifikan terhadap niat perilaku, kontrol perilaku persepsian berpengaruh positif dan signifikan terhadap niat perilaku, gender dalam kontrol perilaku persepsian tidak berpengaruh terhadap niat perilaku, kegunaan persepsi berpengaruh positif dan signifikan terhadap sikap terhadap perilaku, gender dalam kegunaan persepsi berpengaruh positif dan signifikan terhadap sikap terhadap perilaku, kemudahan penggunaan persepsian berpengaruh positif dan signifikan terhadap sikap terhadap perilaku, gender dalam persepsi kemudahan penggunaan tidak berpengaruh terhadap sikap terhadap perilaku.
\end{abstract}

Kata Kunci : Technology Acceptance Model (TAM), Theory of Planned Behavior (TPB), Online Travel Agent (OTA), Niat Perilaku, Gender

\section{ABSTRACT}

So far we have seen many researchers who have researched about Technology Acceptance Model (TAM) and Theory of Planned Behavior (TPB) on behavioral intentions related to e-commerce. However, there is no research on the merging of the two models with the intention of tourist behavior in using a technology. The current research study focuses on the behavioral intentions of tourists visiting Bali by using an Online Travel Agent (OTA) and viewed also from a gender perspective. Respondents in this study amounted to 100 people using purposive sampling methods for sampling techniques with the criteria of tourists who come from outside Bali and use the services of an Online Travel Agent (OTA) to visit Bali. Data analysis technique used in this study is Structural Equation Modeling (SEM) using Smart PLS (Partial Least Square) software. The results of this study indicate that attitudes toward behavior do not affect behavioral intentions, gender in attitudes towards behavior has a negative effect on behavioral intentions, subjective norms have a positive and significant effect on behavioral intentions, gender in subjective norms has a positive and significant effect on behavioral intentions, perceived behavioral control positive 
and significant effect on behavioral intentions, gender in perceived behavioral control has no effect on behavioral intentions, the usefulness of perception has a positive and significant effect on attitudes towards behavior, gender in the use of perception has a positive and significant effect on attitudes toward behavior, ease of use of perception has a positive and significant effect on attitudes towards behavior, gender in the perception of ease of use does not affect attitudes toward behavior.

Keywords : Technology Acceptance Model (TAM), Theory of Planned Behavior (TPB),
Online Travel Agent (OTA), behavioural intention, Gender

\section{PENDAHULUAN}

Selama ini kita melihat sudah banyak peneliti yang meneliti mengenai Technology Acceptance Model (TAM) dan Theory of Planned Behavior (TPB) terhadap niat perilaku yang berhubungan dengan e-commerce. Pada penelitian terdahulu yang menyangkut tentang sistem teknologi informasi, TAM sering digunakan untuk mendasari penelitian penelitian tersebut. Pada TAM, variabel niat (intention) dipengaruhi oleh dua variabel utama yaitu persepsi kemudahan penggunaan dan kegunaan persepsi. Namun di dalam TAM, tidak memasukan pengaruh dari faktor sosial dan faktor kontrol pada perilaku.Pada penelitian - penelitian terdahulu kedua faktor tersebut memiliki pengaruh yang signifikan terhadap perilaku penggunaan teknologi informasi. Di Theory of Planned Behavior (TPB), yang merupakan faktor sosial disebut norma subjektif dan yang merupakan faktor kontrol adalah persepsi kontrol perilaku. Selain itu juga terdapat faktor sikap (attitude) dalam TPB. Melalui teori gabungan TAM dan TPB, dapat dipahami bahwa reaksi dan persepsi pengguna terhadap teknologi dapat mempengaruhi sikapnya dalam penerimaan penggunaan teknologi. (Lisa Noor Ardhiani : 2015).

Sampai saat ini belum ada yang meneliti mengenai Technology Acceptance Model (TAM) dan Theory of Planned Behavior (TPB) terhadap niat perilaku yang berhubungan dengan minat konsumen dalam menggunakan Online Travel Agent (OTA) dan dikaitkan dengan perspektif gender. Sehingga peneliti tertarik untuk meneliti masalah tersebut. Menurut databoks.katadata.co.id pada tahun 2018 Indonesia merupakan negara dengan pertumbuhan E-commerce tercepat di dunia dengan jumlah pertumbuhan sebesar $78 \%$ jauh diatas Meksiko (59\%) yang berada di posisi kedua, dan Filipina (51\%) yang berada di posisi ketiga.

Dengan pesatnya pertumbuhan E-commerce di Indonesia, tidak heran jika hampir semua lini bisnis sudah mulai beralih ke media Internet, salah satunya Travel Agent atau sering disebut Online Travel Agent (OTA). Pada dasarnya Online Travel Agent (OTA) memiliki lingkup bisnis selayaknya travel agen konvensional. Di Indonesia, sudah banyak bermunculan Online Travel Agent (OTA) yang sering kita dengar ada Traveloka, Pegipegi, tiket.com, dll. (Gambar 1.2) Menjamurnya Online Travel Agent (OTA) di Indonesia tidak lepas dari cepatnya pertumbuhan E-commerce di Indonesia (Gambar 1.1) dan juga industri pariwisata Indonesia yang semakin menggeliat dalam beberapa tahun terakhir. Media sosial membuat tempat-tempat wisata Indonesia semakin menjadi primadona, tak hanya bagi wisatawan lokal, namun juga internasional.

Menurut Stevanus Wisnu Wijaya (2016) dalam penelitiannya tentang peran media sosial terhadap desa wisata di daerah Yogyakarta mengatakan bahwa media sosial dalam perspektif pengambilan keputusan wisatawan berperan sebagai alat bantu untuk merencanakan perjalanan wisata, selama perjalanan wisata, dan evaluasi setelah perjalanan wisata. Secara khusus, media sosial mampu berperan untuk keperluan promosi 
wisata, distribusi produk wisata dan komunikasi dalam industri wisata. Salah satu lokasi di Indonesia yang masih menjadi primadona bukan hanya bagi wisatawan domestik, tetapi juga wisatawan mancanegara adalah Pulau Bali. Pada ajang Travellers Choice yang diselenggarakan oleh TripAdvisor, Bali berada di posisi ke 5 dunia berada di bawah London (Inggris), Paris (Prancis), Roma (Italia), dan Kreta (Yunani). Namun di level Asia, Bali menjadi peringkat pertama diatas Phuket (Thailand). (www.liputan6.com) Pada penelitian ini peneliti ingin berfokus untuk menggabungkan peran Technology Acceptane Model (TAM) dengan Theory of Planned Behavior (TPB) yang difokuskan pada Online Travel Agent (OTA). Selain menggabungkan antara Technology Acceptane Model (TAM) dengan Theory of Planned Behavior (TPB), gender juga menjadi keterbaharuan dari penelitian ini.

\section{KAJIAN LITERATUR}

\section{Technology Acceptance Model (TAM)}

Menurut Davis (1989), TAM adalah sebuah teori sistem informasi yang dibuat untuk menerangkan bagaimana penguna mengerti dan mengaplikasikan sebuah teknologi informasi.

\section{Kegunaan Persepsian (Perceived Usefulness)}

Kegunaan Persepsian adalah sejauh mana seseorang yakin bahwa dengan menggunakan teknologi tersebut akan meningkatkan kinerjanya, Davis (1989).

\section{Persepsi Kemudahan Kegunaan (Perceived Ease of Use)}

Persepsi Kemudahan Kegunaan adalah keadaan dimana seseorang yakin bahwa dengan menggunakan teknologi tersebut tidak diperlukan usaha apapun (free of effort), Davis (1989).

\section{Theory of Planned Behavior (TPB)}

TPB adalah peningkatan dari Theory of Reasoned Action (TRA). Theory of Reasoned Action (TRA) menemukan bukti bahwa niat untuk melakukan perbuatan tertentu disebabkan oleh 2 faktor, yaitu norma subjektif dan sikap terhadap perilaku, Fishbein dan Ajzen (1975). Ajzen (1988) menambahkan satu faktor yaitu kontrol perilaku persepsian. Penambahan faktor tersebut mengubah Theory of Reasoned Action (TRA) menjadi Theory of Planned Behavior (TPB).

\section{Sikap Terhadap Perilaku}

Menurut Ajzen (1991), sikap terhadap perilaku ialah kecenderungan untuk menanggapi halhal yang disenangi maupun yang tidak pada segala suatu. Sikap terhadap perilaku dianggap sebagai indikator utama yang mempengaruhi niat berperilaku.

\section{Norma Subjektif}

Kreitner dan Kinicki (2001) mengatakan norma subjektif adalah pengakuan desakan sosial dalam memperlihatkan suatu perilaku khusus.

3. Kontrol Perilaku Persepsian

Menurut Feldmann (1995) kontrol perilaku juga dapat diarikan sebagai pemahaman sederhana maupun kompleksya dalam melakukan perbuatan atas dassar pada pengalaman terdahulu dan kendala yang dapat dicari solusinya ketika melakukan suatu perbuatan. 


\section{Niat Perilaku}

Ajzen (2005) mendefinisikan niat sebagai pengaturan perbuatan yang jika dapat waktu dan kesempatan yang tepat akan diwujudkan dalam bentuk tindakan. Menurut Lisa Noor Ardhiani (2015) niat perilaku ialah suatu keinginan seseorang untuk melakukan suatu perilaku yang tertentu. Seseorang akan melakukan suatu perilaku jika memiliki keinginan untuk melakukannya. Saha dan Theingi (2009) menjelaskan niat perilaku sebagai kemungkinan seseorang untuk melakukan suatu perbuatan tertentu.

\section{KERANGKA PEMIKIRAN}

Mengeksplorasi Niat Perilaku Wisatawan : Pengujian dengan Model

Technology Acceptance Model dan Theory of Planned Behavior

Gender

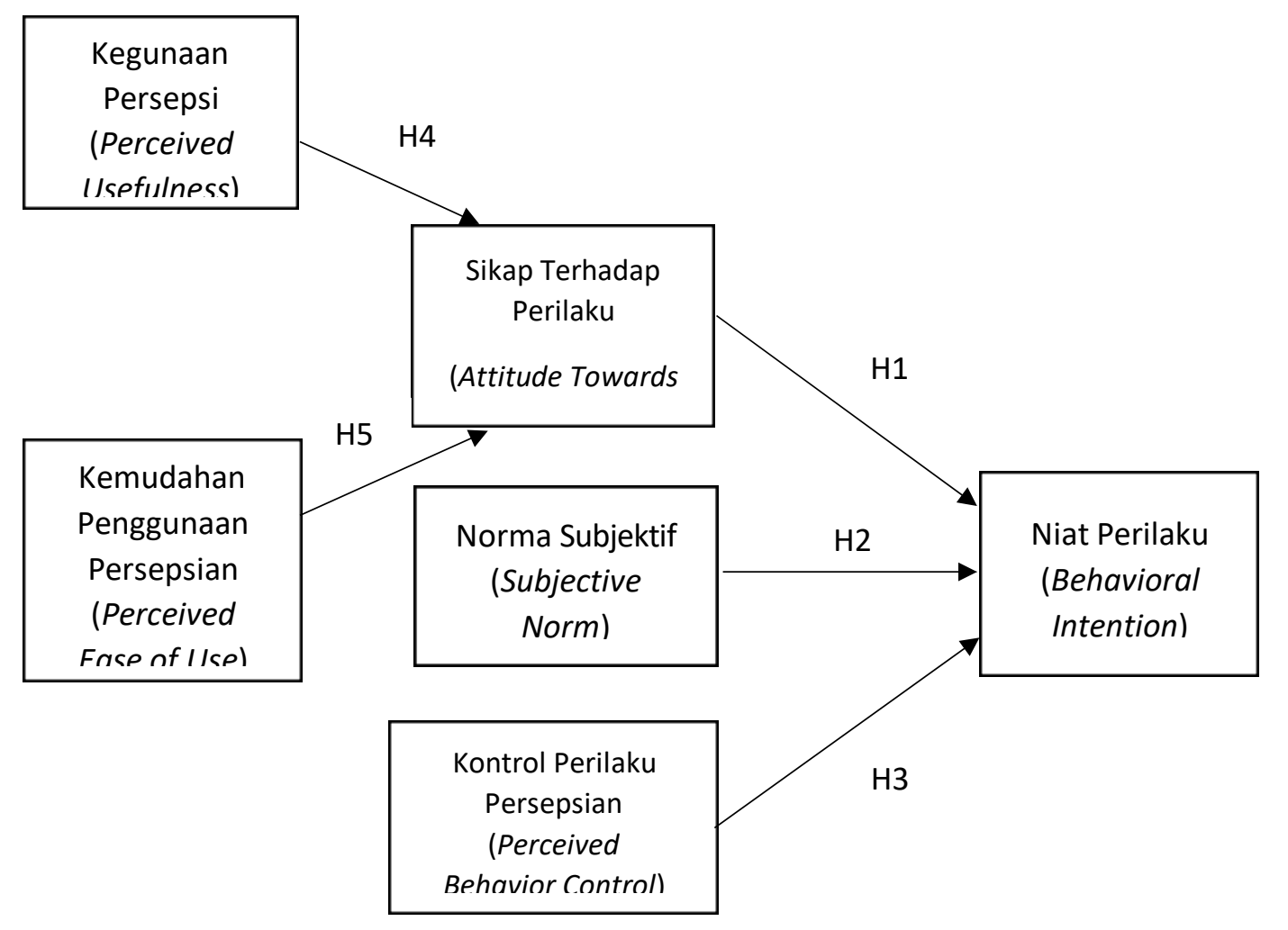

HIPOTESIS PENELITIAN

$\mathrm{H} 1 \mathrm{a}$ : Sikap terhadap perilaku berpengaruh positif dan signifikan terhadap niat perilaku menggunakan Online Travel Agent 
$\mathrm{H} 1 \mathrm{~b}$ : Gender berpengaruh positif dan signifikan dalam sikap

terhadap

perilaku terhadap niat perilaku menggunakan Online Travel Agent

$\mathrm{H} 2 \mathrm{a}$ : Norma subjektif berpengaruh positif dan signifikan terhadap niat perilaku menggunakan Online Travel Agent

$\mathrm{H} 2 \mathrm{~b}$ : Gender berpengaruh positif dan signifikan dalam norma subjektif terhadap niat perilaku menggunakan Online Travel Agent

$\mathrm{H} 3 \mathrm{a}$ : Kontrol perilaku persepsian berpengaruh positif dan signifikan terhadap niat perilaku menggunakan Online Travel Agent

$\mathrm{H} 3 \mathrm{~b}$ : Gender berpengaruh positif dan signifikan dalam kontrol perilaku persepsian terhadap niat perilaku menggunakan Online Travel Agent

$\mathrm{H} 4 \mathrm{a}$ : Kegunaan persepsian berpengaruh positif dan signifikan terhadap sikap terhadap perilaku menggunakan Online Travel Agent

$\mathrm{H} 4 \mathrm{~b}$ : Gender berpengaruh positif dan signifikan dalam kegunaan persepsian terhadap sikap terhadap perilaku menggunakan Online Travel Agent

$\mathrm{H} 5 \mathrm{a}$ : persepsi kemudahan penggunaan berpengaruh positif dan signifikan terhadap sikap terhadap perilaku menggunakan Online Travel Agent

H5b : Gender berpengaruh positif dan signifikan dalam persepsi kemudahan penggunaan terhadap sikap terhadap perilaku menggunakan Online Travel Agent

\section{METODE PENELITIAN}

Lokasi penelitian ini dilakukan kepada wisatawan yang berasal dari luar Pulau Bali. Pendekatan penelitian ini adalah pendekatan kuantitatif. Teknik pengambilan sampel yang digunakan adalah purposive sampling. Responden dalam penelitian ini berjumlah 100 orang dengan menggunakan metode purposive sampling untuk teknik pengambilan sampelnya dengan kriteria wisatawan yang berasal dari luar Bali dan menggunakan jasa Online Travel Agent (OTA) untuk berkunjung ke Bali. Penelitian ini menggunakan data primer yang dikumpulkan melalui kuesioner. Teknik analysis data yang digunakan dalam penelitian ini yaitu Structural Equation Modelling (SEM) yang menggunakan software Smart PLS (Partial Least Square).

\section{HASIL DAN PEMBAHASAN}

\section{Uji Validitas}

Didapat hasil bahwa seluruh butir instrumen dapat dinyatakan valid dan reliabel, Hal tersebut dapat dinyatakan demikian karena seluruh koefisien korelasi lebih besar dibandingkan 0,30. Dengan demikian seluruh butir pernyataan dikatakan valid dan layak digunakan.

\section{Uji Reliabilitas}

Didapat hasil bahwa seluruh variabel dalam penelitian memiliki nilai cronbach's alpha diatas 0,6 . Dengan demikian seluruh variabel reliabel dan layak untuk dianalisis lebih lanjut

\section{Hasil Evaluasi Model Pengukuran (Outer model) \\ Convergent Validity}


dapat dilihat bahwa semua nilai pada uji validitas convergent lebih besar dari 0,7 . Dengan demikian dapat dinyatakan bahwa data dalam penelitian valid.

\section{Discriminat Validity Korelasi Variabel Laten}

dilihat bahwa semua nilai discriminant validity korelasi variabel laten pada masing - masing variabel lebih besar dari 0,7 Dengan demikian dapat dinyatakan bahwa data dalam penelitian valid.

\section{Discriminat Validity Dengan AVE.}

dapat dilihat bahwa semua nilai average variance extracted (AVE) lebih dari 0.5. Dengan demikian dapat dinyatakan bahwa data dalam penelitian valid.

\section{Composite Reliability}

dapat dilihat bahwa semua nilai Cronbach's alpha pada masing - masing variabel lebih besar dari 0,7. Dengan demikian dapat dinyatakan bahwa data dalam penelitian reliabel.

\section{Hasil Evaluasi Model Pengukuran (Inner model)}

\section{R - square}

diperoleh nilai R-square untuk variabel norma subjektif dan kontrol perilaku pengguna terhadap niat perilaku sebesar 0,948 termasuk sangat baik yang menunjukkan memiliki besar pengaruh $0,948 \times 100 \%=94,8 \%$. Nilai R-square untuk variable kegunaan persepsi dan kemudahan penggunaan persepsian terhadap sikap terhadap perilaku sebesar 0,822 termasuk moderat yang menunjukkan memiliki besar pengaruh $0,716 \times 100 \%=82,2$

\section{Q-square}

diperoleh nilai $Q$-square sebesar 0,991 lebih dari 0 dan mendekati 1 , sehingga dapat disimpulkan bahwa model mempunyai nilai predictive relvance atau model layak dikatakan memiliki nilai prediktif yang relevan.

\section{Pembahasan Hasil Penelitian}

\section{Pengaruh Sikap Terhadap Perilaku terhadap Niat Perilaku}

Hasil analisis data menunjukan bahwa nilai $p$-value variabel Sikap Terhadap Perilaku terhadap Niat Perilaku sebesar 0,343 yang dibandingkan dengan signifikan sebesar 0,05. Karena nilai $p$-value < signifikan $(0,343>0,05)$ dengan nilai beta sebesar positif 0,094 dan nilai t statistics sebesar 0,952 yang dibandingkan dengan t-tabel sebesar 1,96. Karena nilai t-statistics $>$ t-value $(0,952<1,96)$ maka dapat disimpulkan bahwa sikap terhadap perilaku tidak berpengaruh terhadap niat perlaku.

Hal ini berarti variabel sikap terhadap perilaku yang diwakilkan dengan indikator sikap penerimaan terhadap system, sikap penolakan terhadap system, dan pengalaman menyenangkan menggunakan system tidak mempengaruhi niat wisatawan dalam menggunakan Online Travel Agent (OTA) untuk memesan tiket guna berkunjung ke Bali.

\section{Pengaruh Gender dalam Sikap Terhadap Perilaku terhadap Niat Pelaku}

Hasil analisis data menunjukan bahwa nilai $p$-value variabel Gender dalam Sikap Terhadap Perilaku terhadap Niat Pelaku sebesar 0,007 yang dibandingkan dengan signifikan sebesar 
0,05 . Karena nilai $p$-value $<$ signifikan $(0,007<0,05)$ dengan nilai beta sebesar negative 0,256 dan nilai t statistics sebesar 2,759 yang dibandingkan dengan t-tabel sebesar 1,96. Karena nilai t-statistics $>$ t-value $(2,759$

$>1,96)$ maka dapat disimpulkan bahwa gender dalam sikap terhadap perilaku berpengaruh negative terhadap niat perilaku.

Hal ini berarti gender dalam variabel sikap terhadap perilaku yang diwakilkan dengan indikator sikap penerimaan terhadap system, sikap penolakan terhadap system, dan pengalaman menyenangkan menggunakan system mempengaruhi secara negatif niat wisatawan dalam menggunakan Online Travel Agent (OTA) untuk memesan tiket guna berkunjung ke Bali.

Berdasarkan hasil analisis data didapat hasil nilai $p$-value variabel Norma Subjektif terhadap Niat Perilaku sebesar 0,000 yang dibandingkan dengan signifikan sebesar 0,05. Karena nilai $p$-value $<$ signifikan $(0,000<0,05)$ dengan nilai beta sebesar positif 0,660 dan nilai t statistics sebesar 5,819 yang dibandingkan dengan t-tabel sebesar 1,96. Karena nilai t-statistics $>$ t-value $(5,819$

$>1,96)$ maka dapat disimpulkan bahwa norma subjektif berpengaruh positif dan signifikan terhadap niat perlaku.

Hal ini berarti variabel norma subjektif yang diwakilkan dengan indikator pengaruh teman sebaya, pengaruh orang yang dianggap penting, motivasi untuk memenuhi saran dari teman sebaya, dan motivasi untuk memenuhi saran dari orang yang dianggap penting mempengaruhi niat wisatawan dalam menggunakan Online Travel Agent (OTA) untuk memesan tiket guna berkunjung ke Bali.

\section{Pengaruh Gender dalam Norma Subjektif terhadap Nilai Perilaku}

Sesuai dengan hasil analisis data maka didapat hasil yaitu nilai $p$-value variabel Gender dalam Norma Subjektif terhadap Nilai Perilaku sebesar 0,040 yang dibandingkan dengan signifikan sebesar 0,05 . Karena nilai $p$-value $>$ signifikan $(0,040<0,05)$ dengan nilai beta sebesar positif 0,247 dan nilai t statistics sebesar 2,080 yang dibandingkan dengan t-tabel sebesar 1,96. Karena nilai t- statistics < t-value $(0,2,080>1,96)$ maka dapat disimpulkan bahwa gender dalam norma subjektif berpengaruh positif dan signifikan terhadap niat perilaku.

Hal ini berarti gender dalam variabel norma subjektif yang diwakilkan dengan indikator pengaruh teman sebaya, pengaruh orang yang dianggap penting, motivasi untuk memenuhi saran dari teman sebaya, dan motivasi untuk memenuhi saran dari orang yang dianggap penting mempengaruhi niat wisatawan dalam menggunakan Online Travel Agent (OTA) untuk memesan tiket guna berkunjung ke Bali

\section{Pengaruh Kontrol Perilaku Persepsian terhadap Niat Perilaku}

Berdasarkan hasil analisis data didapat hasil nilai $p$-value variabel Kontrol Perilaku Persepsian terhadap Niat Perilaku sebesar 0,020 yang dibandingkan dengan signifikan sebesar 0,05 . Karena nilai $p$-value < signifikan $(0,020<0,05)$ dengan nilai beta sebesar positif 0,275 dan nilai t statistics sebesar 2,373 yang dibandingkan dengan t-tabel sebesar 1,96. Karena nilai t-statistics $>$ t-value $(2,373>1,96)$ maka dapat disimpulkan bahwa kontrol perilaku persepsian berpengaruh positif dan signifikan terhadap niat perilaku.

Hal ini berarti variabel pengaruh kontrol perilaku yang diwakilkan dengan indikator kemampuan dan kemauan diri serta kondisi fasilitas sumber daya dan teknologi 
mempengaruhi niat wisatawan dalam menggunakan Online Travel Agent (OTA) untuk memesan tiket guna berkunjung ke Bali.

\section{Pengaruh Gender dalam Kontrol Perilaku Persepsian terhadap Niat Perilaku}

Berdasarkan hasil analisis data didapat hasil nilai $p$-value variabel Gender dalam Kontrol Perilaku Persepsian terhadap Niat Perilaku sebesar 0,718 yang dibandingkan dengan signifikan sebesar 0,05 . Karena nilai $p$-value $<$ signifikan $(0,718>0,05)$ dengan nilai beta sebesar positif 0,036 dan nilai t statistics sebesar 0,362 yang dibandingkan dengan t-tabel sebesar 1,96 . Karena nilai t-statistics $>$ t- value $(0,718<1,96)$ maka dapat disimpulkan bahwa gender dalam kontrol perilaku persepsian tidak berpengaruh terhadap niat perilaku.

Hal ini berarti gender dalam variabel pengaruh kontrol perilaku yang diwakilkan dengan indikator kemampuan dan kemauan diri serta kondisi fasilitas sumber daya dan teknologi tidak mempengaruhi mempengaruhi niat wisatawan dalam menggunakan Online Travel Agent (OTA) untuk memesan tiket guna berkunjung ke Bali.

\section{Pengaruh Kegunaan Persepsi terhadap Sikap Terhadap Perilaku}

Berdasarkan hasil analisis data didapat hasil nilai $p$-value variabel Kegunaan Persepsi terhadap Sikap Terhadap Perilaku sebesar 0,001 yang dibandingkan dengan signifikan sebesar 0,05 . Karena nilai $p$-value $>$ signifikan $(0,001<0,05)$ dengan nilai beta sebesar positif 0,681 dan nilai t statistics sebesar 3,456 yang dibandingkan dengan t-tabel sebesar 1,96. Karena nilai t-statistics < t- value $(3,456>1,96)$ maka dapat disimpulkan bahwa kegunaan persepsi berpengaruh positif dan signifikan terhadap sikap terhadap perilaku.

Hal ini berarti variabel kegunaan persepsi yang diwakilkan dengan indikator efektivitas, manfaat, dan produktivitas mempengaruhi sikap terhadap perilaku wisatawan dalam menggunakan Online Travel Agent (OTA) untuk memesan tiket guna berkunjung ke Bali.

\section{Pengaruh Gender dalam Kegunaan Persepsi terhadap Sikap Terhadap Perilaku}

Berdasarkan hasil analisis data didapat hasil nilai $p$-value variable Gender dalam Kegunaan Persepsi terhadap Sikap Terhadap Perilaku sebesar 0,007 yang dibandingkan dengan signifikan sebesar 0,05 . Karena nilai $p$-value < signifikan $(0,007<0,05)$ dengan nilai beta sebesar positif 0,461 dan nilai t statistics sebesar 2,740 yang dibandingkan dengan t-tabel sebesar 1,96 . Karena nilai t-statistics $>t$ - value $(2,740>1,96)$ maka dapat disimpulkan bahwa gender dalam kegunaan persepsi berpengaruh positif dan signifikan terhadap sikap terhadap perilaku.

Hal ini berarti gender dalam variabel kegunaan persepsi yang diwakilkan dengan indikator efektivitas, manfaat, dan produktivitas mempengaruhi sikap terhadap perilaku wisatawan dalam menggunakan Online Travel Agent (OTA) untuk memesan tiket guna berkunjung ke Bali.

\section{Pengaruh Kemudahan Penggunaan Persepsian terhadap Sikap Terhadap Perilaku}

Berdasarkan hasil analisis data didapat hasil nilai $p$-value variabel Kemudahan Penggunaan Persepsian terhadap Sikap Terhadap Perilaku sebesar 0,000 yang dibandingkan dengan signifikan sebesar 0,05 . Karena nilai $p$-value $<$ signifikan $(0,000<$ $0,05)$ dengan nilai beta sebesar positif 0,664 dan nilai t statistics sebesar 3,705 yang dibandingkan dengan t-tabel sebesar 1,96 . Karena nilai t- statistics $>$ t-value $(3,705>1,96)$ maka dapat disimpulkan bahwa kemudahan penggunaan persepsian berpengaruh positif dan signifikan terhadap sikap terhadap perilaku. 
Hal ini berarti variabel kemudahan penggunaan persepsi yang diwakilkan dengan indikator mudah digunakan, mudah dipahami, dan fleksibel mempengaruhi sikap terhadap perilaku wisatawan dalam menggunakan Online Travel Agent (OTA) untuk memesan tiket guna berkunjung ke Bali.

\section{Pengaruh Gender dalam Persepsi Kemudahan Pengunaan terhadap Sikap Terhadap Perilaku}

Berdasarkan hasil analisis data didapat hasil Nilai $p$-value variable Gender dalam Persepsi Kemudahan Penggunaan Terhadap Sikap Terhadap Perilaku sebesar 0,961 yang dibandingkan dengan signifikan sebesar 0,05 . Karena nilai $p$-value $>$ signifikan $(0,961>$ $0,05)$ dengan nilai beta sebesar positif 0,009 dan nilai t statistics sebesar 0,050 yang dibandingkan dengan t-tabel sebesar 1,96. Karena nilai t-statistics $<\mathrm{t}$-value $(0,050<1,96)$ maka dapat disimpulkan bahwa genderdalam persepsi kemudahan penggunaan tidak berpengaruh terhadap sikap terhadap perilaku.

Hal ini berarti gender dalam variabel kemudahan penggunaan persepsi yang diwakilkan dengan indikator mudah digunakan, mudah dipahami, dan fleksibel tidak mempengaruhi sikap terhadap perilaku wisatawan dalam menggunakan Online Travel Agent (OTA) untuk memesan tiket guna berkunjung ke Bali. 


\section{KESIMPULAN DAN SARAN}

\section{Kesimpulan}

Berdasarkan hasil analisis penelitian dan hasil pembahasan pada bab sebelumnya maka simpulan dari penelitian ini adalah sebagai berikut:

1. sikap terhadap perilaku yang diwakilkan dengan indikator sikap penerimaan terhadap system, sikap penolakan terhadap system, dan pengalaman menyenangkan menggunakan system tidak mempengaruhi niat wisatawan dalam menggunakan Online Travel Agent (OTA) untuk memesan tiket guna berkunjung ke Bali.

2. Hal ini berarti gender dalam variabel sikap terhadap perilaku yang diwakilkan dengan indikator sikap penerimaan terhadap system, sikap penolakan terhadap system, dan pengalaman menyenangkan menggunakan system mempengaruhi secara negatif niat wisatawan dalam menggunakan Online Travel Agent (OTA) untuk memesan tiket guna berkunjung ke Bali.

3. Hal ini berarti variabel norma subjektif yang diwakilkan dengan indikator pengaruh teman sebaya, pengaruh orang yang dianggap penting, motivasi untuk memenuhi saran dari teman sebaya, dan motivasi untuk memenuhi saran dari orang yang dianggap penting mempengaruhi niat wisatawan dalam menggunakan Online Travel Agent (OTA) untuk memesan tiket guna berkunjung ke Bali.

4. Hal ini berarti gender dalam variabel norma subjektif yang diwakilkan dengan indikator pengaruh teman sebaya, pengaruh orang yang dianggap penting, motivasi untuk memenuhi saran dari teman sebaya, dan motivasi untuk memenuhi saran dari orang yang dianggap penting mempengaruhi niat wisatawan dalam menggunakan Online Travel Agent (OTA) untuk memesan tiket guna berkunjung ke Bali

5. Hal ini berarti variabel pengaruh kontrol perilaku yang diwakilkan dengan indikator kemampuan dan kemauan diri serta kondisi fasilitas sumber daya dan teknologi mempengaruhi niat wisatawan dalam menggunakan Online Travel Agent (OTA) untuk memesan tiket guna berkunjung ke Bali.

6. Hal ini berarti gender dalam variabel pengaruh kontrol perilaku yang diwakilkan dengan indikator kemampuan dan kemauan diri serta kondisi fasilitas sumber daya dan teknologi tidak mempengaruhi mempengaruhi niat wisatawan dalam menggunakan Online Travel Agent (OTA) untuk memesan tiket guna berkunjung ke Bali.

7. Hal ini berarti variabel kegunaan persepsi yang diwakilkan dengan indikator efektivitas, manfaat, dan produktivitas mempengaruhi sikap terhadap perilaku wisatawan dalam menggunakan Online Travel Agent (OTA) untuk memesan tiket guna berkunjung ke Bali.

8. Hal ini berarti gender dalam variabel kegunaan persepsi yang diwakilkan dengan indikator efektivitas, manfaat, dan produktivitas mempengaruhi sikap terhadap perilaku wisatawan dalam menggunakan Online Travel Agent (OTA) untuk memesan tiket guna berkunjung ke Bali.

9. Hal ini berarti variabel kemudahan penggunaan persepsi yang diwakilkan dengan indikator mudah digunakan, mudah dipahami, dan fleksibel mempengaruhi sikap terhadap perilaku wisatawan dalam menggunakan Online Travel Agent (OTA) untuk memesan tiket guna berkunjung ke Bali. 
10. Hal ini berarti gender dalam variabel kemudahan penggunaan persepsi yang diwakilkan dengan indikator mudah digunakan, mudah dipahami, dan fleksibel tidak mempengaruhi sikap terhadap perilaku wisatawan dalam menggunakan Online Travel Agent (OTA) untuk memesan tiket guna berkunjung ke Bali.

\section{Saran}

Hasil dari penelitian ini diharapkan dapat memberikan sumbangan kajian teoritis yang menjadi bahan pertimbangan serta sebagai gambaran bagi masyarakat tentang niat perilaku wisatawan dilihat dari pengujian dengan model Technology Acceptance Model dan Theory of Planned Behavior serta dilihat dari perspektif gender. Selain itu, hasil penelitian ini dapat dipergunakan oleh Online Travel Agent dapat memperbaiki kinerja perusahaan mereka, hal ini dikarenakandalam proses pengambilan keputusan konsumen dalam menggunakan jasa online travel agent dipengarhi oleh bagaimana sikap konsumen dalam mengadopsi dan menerima teknologi yang ditawarkan oleh perusahaan. Selain itu juga peran lingkungan sekitar juga turut mempengaruhi proses pengambilan keputusan oleh konsumen. IBagi peneliti selanjutnya, dapat menambahkan beberapa variabel lain untuk menguji lebih dalam tentang niat perilaku wisatawan dalam menggunakan Online Travel Agent (OTA). Seperti contoh, variabel Country Of Origin atau variabel niat pembelian ulang.

\section{DAFTAR PUSTAKA}

Ajzen, I. 1988. Attitudes, Personality, and Behavior. Milton-Keynes, England: Open University Press \& Chicago, IL: Dorsey Press

Ajzen, I., 1991, The Theory of Planned Behavior, Organizational Behavior and Human Decision Processes

Ajzen, I., \& Fishbein, M., 1975, Belief, Attitude, Intention, and Behavior: An Introduction to Theory and Research, 129-385, Addison-Wesley, Reading, MA.

Ajzen, I., 2005, Attitudes, Personality and Behavior, 2nd Edition, McGraw-Hill Professional Publishing, Berkshire, GBR.

Ardhiani, Lisa Noor, 2015, Analisis Faktor-Faktor Penerimaan Penggunaan Quipperschool.Com Dengan Menggunakan Pendekatan Technology Acceptance Model (TAM) Dan Theory Of Planned Behavior (Tpb) Di Sma Negeri 7 Yogyakarta, Skripsi Universitas Negeri Yogyakarta

Abdoelmaged, Mohamed Gamal, 2009. Predicting e-procurement adoption in a developing country. An empirical integration of technology acceptance model and theory of planned behavior. Ajman University of Science and Technology, Ajman, United Arab Emirates.

Amber S. Emanuel, Scout N.Mc.Cully, Kristen M.Gallagher, John A.Updegraff.2012. Theory of Planned Behavior explains gender differences in fruit and vegetable consumption. Departement of Psychology.Kent State University. Kent.USA

Australian Tourism Data Wirehouse. 2013.Tutorial 39a On Line Travel Agents 101.Australia: Australian Tourism Data Warehouse.

Davis, F. 1989. Perceived Usefulness, Perceived Ease of Use, and User Acceptance of Information Technology. MIS Quarterly (13:3), pp. 319- 339.

Feldman, Robert S. 1995. Social Psychology. New Jersey : A Simaon \& Schuster Company. Englewood Cliffs. 
Janal,D.S.2005. Online Marketinghandbook : how to sell, advertise, publicize and promote your products and services on the internet and commercial online system. NewYork : Van Nostrand Reinhold

Kreitner, Robert and Angelo Kinicki, 2001. Organizational Behavior. Fifth Edition.

Irwin McGraw-Hill.

Leong Lai-Ying, Keng-Boon Ooi, Alain Yee-Loong Chong, Binshan Lin. 2013. Modelling The Stimulators of the Behavioral Intention to use mobile entertainment : does gender really matter? Computers in Human Behavior

Muslim Amin, Sajad Rezaei, and Firouseh Shajari Tavana. 2015. Gender differences and consumer repurchase intention : the impact of trust propensity, usefulness and ease of use for implication of innovative online retail. Int.j.Innovation and Learning, Vol.17

Ramadqan, Mohamad Insan dan Dewi Sri Andika Rusmana, 2017. Potensi Media Sosial Sebagai Sarana Media Promosi Pariwisata Berbasis Partisipasi Masyarakat. Universitas Tujuh Belas Agustus 1945, Surabaya.

Ruizsalba Jose, Maria Valespin, Victor Martin, Miguel Molina. 2014. The moderating role of gender entrepreneurial intentions : A TPB perspective. The Claude Littner Bussiness School. University of West London.

Saha, G, C., \& Theingi., 2009, Service Quality, Satisfaction, and Behavioral Intentions: A Study of low cost Airline Carriers in Thailand. The TQM Journal

Wijaya, Stevanus Wisnu. 2016. Media Sosial bagi Desa Wisata: Sebuah Kajian Konseptual. Fakultas Sains dan Teknologi Universitas Sanata Dharma Yogyakarta. 